\title{
Sï.تmL
}

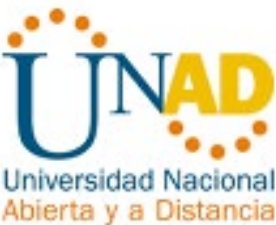

\section{A MULTIDIMENSIONAL ANALYSIS FOR THE MANAGEMENT OF RESEARCH PROJECTS IN BUSINESS FACULTIES}

\author{
Abel Del Río Cortina \\ Estudiante Doctoral \\ Gerencia de Proyectos Universidad EAN \\ adelrioc2311@universidadean.edu.co \\ Johan Manuel Redondo \\ PhD. Professor. \\ Universidad Católica de Colombia \\ jmredondo@ucatolica.edu.co
}

According to Hekkert, et al (2011), the Science, Technology and Innovation Systems (SCTeI) function as macrostructures in which converge different actors promoting the generation and application of knowledge.

Science, Technology and Innovation Systems require the design of research strengthening strategies to be applied in response to the demands of the academic community, the productive sector, and society in general, being these strategies a guideline on the development of educational programs and research processes.

Business faculties follow international dynamics looking for the necessary improvement in order to be competitive, and that is why research projects have a relevant participation on the transformation of business education through the generation and increase of organizational capabilities related to maturity models (Backlund; et al, 2015).

At this respect, Backlund, et al (2015), analyze the literature about maturity models getting to two complementary basic definitions. At a first moment maturity models are organizational structures that reflect certain capabilities and define qualitative attributes, which are applied to classify competences into pre-defined areas (Kohlegger et al., 2009); later on, the authors consider 


\section{รื่อm}

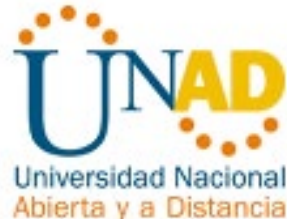

that maturity models refer to the state where an organization could perfectly achieve its objectives.

The management of research projects in business faculties has the inherent complexity of the challenges of the Institutions of Higher Education in the context of internationalization (Guillotin, \& Mangematin, 2015), requiring mechanisms that, framed on strategic management models (Kerzner, 2001; David, 2003; Resch, 2011; EFQM, 2012), tend to generate better interventions in a systemic scenario through relevant projects, which, in turn, should strengthen curricular development, and provide organizational capabilities (Backlund; et al, 2015). Consider that research projects, in general, have the basic elements of delay, feedback and accumulation within cause and effect dynamics, corresponding to a complex scenery (Forrester, 1961; Sterman; et al, 2015; Redondo; et al, 2017).

The above considerations imply a permanent analysis of project performance, and the adoption of the parameters of Colciencias (2017), the National Accreditation Council (CNA) (2013), and the guidelines of international accrediting bodies such as AACSB (2016), AMBA (2016), EQUIS (2016), IACBE, and ACBSP, as well as the analysis of the needs of the different stakeholders involved, this, in order to visualize better routes for improvement.

Any approach to the proposal of strategies to improve the results of research projects should start from an analysis of the particular context of each faculty, with the support of validated management models, in correspondence with the institutional strategic thinking and with the requirements of the academic community that is directly impacted (Bennis and O'Toole, 2005; Malaver, 2006; Besancenot, Ricardo and Vranceanu, 2009; Calderón, et al., 2010; AACSB, 2012; Calderón, et al., 2014; and, Sahoo, et al., 2016). 


\section{ㄷi른}

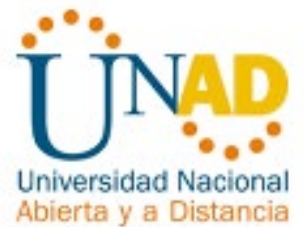

Having this in mind, in this paper there are shown two project management dimensions based on a literature review with the purpose of getting a theoretical approach to the variables that composed the dimensions.

The first dimension corresponds to the processes of the project life cycle, and the second one corresponds to the knowledge derived from the product life cycle.

Taking into account the paths from the Project Management Institute (PMBOK, 2017), the project life cycle has four phases, being these, conceptual, planning, execution, and termination.

When talking about research projects for business faculties, it is proposed a structure composed by eight phases, being these, (a) institutional call, (b) proposals, (c) analysis of the proposals, (d) communication of results, (e) execution of the projects, (f) follow-up, (g) completion of products, and (h) closing.

The product life cycle has five stages, development, introduction, growth, maturity, and retirement (PMBOK, 2017), being the products gotten from academic research classified as products of new knowledge generation, technical development and innovation, social appropriation of knowledge, and training of human resources.

In this way, the project life cycle corresponds to the administrative management and the product life cycle corresponds to the knowledge management.

According to the literature review, the project life cycle is impacted by seven variables which are organizational culture, as a mechanism that influences the acceptance or rejection of processes (Dueholm., et al, 2013); communication, as a media that connects the different stakeholders (Monteiro de Carvalho, 2013); team performance, as the way the different activities are done into the project focus on its success (Backlund; et al, 2015; Coetzer, 2016); 


\section{รi்่า \\ C O L O M B I A}

stakeholder management, as the analysis and establishment of proper relationships for project success (Iden \& Bygstad, 2017); best practices, as the adoption and documentation of the best processes (Kahn; et al, 2006); management model, as the administrative path in order to get the best results (Abushama, 2016); and strategic thinking, as the strategic route to be followed into the project planning and execution processes (Shenhar; et al, 2001).

In the case of product life cycle, it is taken as a basic reference the proposal of Bharadwaj, and Tiwana (2005), in which there are considered seven variables related to knowledge management, knowledge creation, as the process of development of new knowledge; knowledge exploitation, as the process of utilizing preexisting organizational knowledge applying it in different contexts to the ones it was originally developed; knowledge digitalization, as the process of codification of the information; knowledge integration, as the coordinated application of individual-held specialist knowledge to collective activities; knowledge sharing, as the process of sharing specialized tacit and explicit knowledge; and knowledge appropriability, as a process that facilitates knowledge sharing and application.

A deep analysis of the interactions of the variables that composed the two dimensions make it possible to generate some reflections about new strategies in terms of decision making, organizational capacities, resources demand, and about the analysis of research project approval criteria, this, in order to formulate and approve projects that tend to be successful. 


\section{Sİป}

\section{REFERENCES}

- Hekkert, M., Negro, S., Heimeriks, G., \& Harmsen, R. (2011). Technological innovation system analysis. Faculty of Geosciences Utrecht University.

- Backlund, F., Chronéer, D., \& Sundqvist, E. (2015). Maturity assessment: towards continuous improvements for project-based organisations?. International Journal of Managing Projects in Business, DOI: 10.1108/IJMPB-05-2014-0047.

- Kohlegger, M., Maier, R. and Thalmann, S. (2009), "Understanding maturity models - Results of a structured content analysis", in Proceedings of IKNOW'09 and I-SEMANTICS'09, Graz, Austria, pp. 51-61.

- Guillotin, B., y Mangematin, V., (2015). Internationalization Strategies of Business Schools: How Flat Is the World?. Thunderbird International Business Review, DOI: 10.1002/tie.

- Kerzner, H., (2001). Strategic planning for project management using a project management maturity model. New York, New York, John Wiley \& Sons, Inc.

- David, F., (2003). Conceptos de administración estratégica. México, Pearson Education.

- Resch, M., (2011). Strategic Project Management Transformation, Delivering Maximum ROI \& Sustainable Business Value. J.Ross Publishing, U.S.A.

- European Foundation for Quality Management, (2012). EFQM Excellence Model 2013, EFQM Publications, Bruxelles, Belgium.

- Forrester, J., (1966). Principlies of systems, M.I.T. Press.

- Sterman, J., Oliva, R., Linderman, K., y Bendoly, E., (2015). System dynamics perspectives and modeling opportunities for research in operations management, Journal of Operations Management. 


\section{silem}

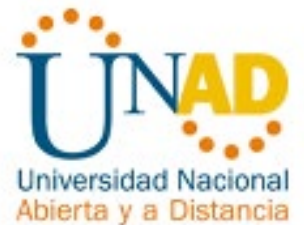

- Redondo, J.M., Olivar, G., Ibarra, D., \& Dyner, I. (2017). Modeling for the regional integration of electricity markets. Energy for sustainable development, Vol 43 pp 100-113.

- Colciencias, (2017). Modelo de medición de grupos de investigación, desarrollo tecnológico o de innovación y de reconocimiento de investigadores del Sistema nacional de ciencia, tecnología e innovación, año 2017. Bogotá.

- Consejo Nacional de Acreditación, (2013). Lineamientos para la acreditación de programas de pregrado. Bogotá, CNA.

- AACSB, (2016). Advancing Quality Management Education Worldwide. AACSB international. Retrieved from: http://www.aacsb.edu/membership/listings/all-educational-members/

- AMBA, (2016). AMBA accredited business schools. Association of MBAs. Ubicado en: http://community.mbaworld.com/accredited schools/

- EQUIS, (2016). Equis accredited schools. Retrieved from https://www.efmd.org/accreditation-main/equis/accredited-schools.

- Bennis, W., y O'toole, J., (2005). How Business Schools Lost Their Way. Harvard Business Review. Retrieved from https://hbr.org/2005/05/howbusiness-schools-lost-their-way

- Malaver, F., (2006). El despegue de la investigación Colombiana en administración: análisis de sus avances en el período 2000-2006. Cuadernos de administración, Bogotá. Vol 19, pp. 71-109.

- Besancenot, D., Ricardo, J., y Vranceanu, R., (2009). Why business schools do so much research: A signaling explanation. Research Policy, Vol 38, pp. 1093-1101.

- Calderón, G., Arrubla, J., Castaño, G., Gutiérrez, L., Posada, R., Ruiz, A., y Vivares, J., (2010). La investigación en administración en Colombia. Condiciones para la generación de conocimiento, investigadores, 
Silizm,

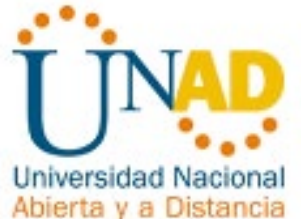

institucionalización y producción científica. Medellín, Asociación Colombiana de Facultades de Administración (Ascolfa).

- AACSB, (2012). Impact of research, a guide for business schools. AACSB international.

Retrieved

from:

\section{http://www.aacsb.edu/ /media/AACSB/Publications/research-}

\section{reports/impact-of-research-exploratory-study.ashx}

- Calderón, G., Castaño, G., Lozada, N., Gutiérrez, L., Pérez, P., y Posada, R., (2014). Generación de conocimiento en los grupos élite de investigación en administración en Colombia. Bogotá, Universidad Nacional de Colombia.

- Sahoo, B., Singh, R., Mishra, B., Sankaran, K., et al., (2016). Research productivity in Management Schools of India during 1968-2015: A directional benefit-of-doubt. OMEGA The International Journal of Management Science, Vol.13, No. 3, pp. 163-168.

- Project Management Institute., (2017). A guide to the project management body of knowledge PMBOK® Guide 6th Ed. Newtown Square, PA.

- Dueholm Müller, S., \& Axel Nielsen, P. (2013). Competing values in software process improvement: a study of cultural profiles. Information Technology \& People, DOI: 10.1108/ITP-03-2013-0052.

- Monteiro de Carvalho, M. (2013). An investigation of the role of communication in IT projects. International Journal of Operations \& Production Management, DOI: 10.1108/IJOPM-11-2011-0439.

- Coetzer, G. (2016). An empirical examination of the relationship between adult attention deficit and the operational effectiveness of project managers. International Journal of Managing Projects in Business, DOI: 10.1108/IJMPB-01-2016-0004.

- Iden, J., \& Bygstad, B. (2017). The social interaction of developers and IT operations staff in software development projects. International Journal of Project Management, DOI: 10.1016/j.ijproman.2017.12.001. 


\section{Silizm}

- Kahn, K. B., Barczak, G., \& Moss, R. (2006). Perspective: Establishing an NPD Best Practices Framework. Journal of product innovation management, DOI: $10.1111 / \mathrm{j} .1540-5885.2006 .00186 . x$.

- Abushama, H. M. (2016). PAM-SMEs: process assessment method for small to medium enterprises. Journal of Software: Evolution and Process, DOI: 10.1002/smr.1793.

- Shenhar, A. J., Dvir, D., Levy, O., \& Maltz, A. C. (2001). Project success: A multidimensional strategic concept. Long Range Planning, DOI: 10.1016/S0024-6301(01)00097-8.

- Bharadwaj, A., \& Tiwana, A. (2005). Managerial assessments of e-business investment opportunities: A field study. IEEE Transactions on Engineering Management, DOI: 10.1109/TEM.2005.856573. 